\title{
Chapter 6 Education based on sustainability: A life in balance
}

\section{Capítulo 6 Educación basada en la sostenibilidad: Una vida en equilibrio}

PLACENSIA-VALERIO, Arely Yamile†*, PATRON-HERNANDEZ, Gladys Concepción and SANCHEZ-MORALES, Yessica Valeria

Universidad Autónoma de Campeche / Higher School of Agricultural Sciences. Calle $53 \mathrm{~s} / \mathrm{n}$. Col. Unidad Esfuerzo y Trabajo. C.P. 24350 Escárcega, Campeche

ID $1^{\text {st }}$ Author: Arely Yamile, Placensia-Valerio / ORC ID: 0000-0001-6492-7276

ID $1^{\text {st }}$ Coauthor: Gladys Concepción, Patron-Hernandez

ID $2^{\text {nd }}$ Coauthor: Yessica Valeria, Sanchez-Morales

DOI: $10.35429 / \mathrm{H} .2021 .8 .102 .116$ 


\begin{abstract}
In this paper, mention is made of the concept of sustainability, its principles, foundations and main objectives; how to implement them in daily life for society, achieving a quality life, because of the large demands on the production of products, the provision of services and new technologies, and its efficient implementation has been reduced. Sustainable development has been developed but not as initially established, as one of its objectives is to maintain a balance between social, economic and environmental factors, without affecting natural resources for future generations, highlighting a factor of great importance for its realization; education, since it allows to introduce the knowledge, skills, values, and principles of sustainability, from the basic level, to the higher school level, facilitating skills and promoting awareness of the value of having a quality life, provided that it meets the requirements of the interrelation with the environment, in addition to those that you have with each of the factors to be able to implement effectively.
\end{abstract}

\title{
Balance, Quality, Sustainability
}

\section{Resumen}

En este trabajo se hace mención al concepto de sustentabilidad, sus principios, fundamentos y principales objetivos; cómo implementarlos en la vida diaria de la sociedad, logrando una calidad de vida, debido a las grandes exigencias en la producción de productos, la provisión de servicios y nuevas tecnologías, y se ha reducido su implementación eficiente. El desarrollo sostenible se ha desarrollado pero no como se estableció inicialmente, ya que uno de sus objetivos es mantener un equilibrio entre los factores sociales, económicos y ambientales, sin afectar los recursos naturales para las generaciones futuras, destacando un factor de gran importancia para su realización; educación, ya que permite introducir los conocimientos, habilidades, valores y principios de la sostenibilidad, desde el nivel básico, hasta el nivel superior, facilitando habilidades y promoviendo la conciencia del valor de tener una vida de calidad, siempre que cumpla con los requisitos. de la interrelación con el medio ambiente, además de los que tienes con cada uno de los factores para poder implementar de manera efectiva.

\section{Calidad, Equilibrio, Sostenibilidad}

\section{Introduction}

There have been outstanding contributions through scientific and technological advances, which currently help improve living standards, mainly in industrialized countries. This increases the demand for production and acquisition of products, and at the same causes as a result, a minimization of the importance of product development implemented sustainably by current and future generations. It is essential to mention the influence that education has and can have regarding sustainable development. It allows instilling in society from an early age all the knowledge, values, skills, and objectives needed to carry out sustainable development while promoting a better quality of life. It helps establish a balance between all the sectors involved in society, such as the social, economic, environmental factors, to mention some of the main ones.

The main characteristics that allow the development of a sustainable production process are revealed and are precisely the key objectives to reach the goal of a quality life, with the iteration of all factors being in balance. We should mention how this movement arose and which were the main reasons why it was promoted for adoption by society. Also, pointing out which are the advantages of being able to carry it out in an efficient way, either when exercising it individually or in groups, having clear the fulfillment of the objectives in the collaboration of teamwork for better performance and efficiency, promoting the balance in the sustainable product development.

The environmental crisis has reached such an alarming level that it is now necessary, through education, to become aware of the importance of changing the forms of production and social welfare, respect for cultural diversity, and conditions that make possible the existence of life on the planet. In this context, the importance of sustainable education becomes evident as one of the alternatives for the recognition of the value of the conservation of the planet's natural conditions. In recent years, education has been linked to sustainable development. 
Although sustainability is a complex process because it demands the availability of a great variety of resources and conditions to generate collective benefits, it is necessary to rely on the existing means to try to create a system of education that privileges human conscience and rationality before the exploitation and degradation of the environment that threatens humanity itself; that is to say, a system of sustainable education. An education based on environmental knowledge, strengthening actions to contribute to the transformation of the population, and the ecological preservation of the planet attempts to minimize the problems caused by the environmental crisis in the future on a worldwide level.

\section{Background of education for efficient sustainability}

The negative impacts resulting from climate change or ocean pollution, to name a few, lead us to speak of an environmental crisis, which also adds to the challenge of societies to seek a balance between product development and environmental protection. It is therefore extremely necessary to contribute to the training of people who in turn can influence good practices towards the surrounding environment. This would result in not only individual actions, not only the realization of the damage caused by the actions of human beings on the planet, but collective actions that generate a social transformation and promote better performance.

Several environmental organizations and activists arose around the world whose goal was the conservation of nature, trying to raise awareness among the population, companies, and governments about the effects that human activities were generating in our natural environment. Likewise, they sought to produce legal and transforming changes that would allow us to live in harmony with the environment. In this way, teaching about ecology constitutes one of the first attempts to link education with the care of nature. This type of teaching should be emphasized since it was centered on the conservation of natural resources. It was also a great contribution to sustainable education since it would allow the expansion of horizons and would begin to incorporate the sociocultural, political, and economic dimensions. In this way, education evolved from a vision based on the knowledge of the natural environment to another that considers the natural and sociocultural built environment, as well as people as a whole with their different traits such as values, emotions, feelings, and reasoning.

The most important characteristics are centered on the fact that it is theoretical-practical since it leads to the resolution of concrete problems based on environmental knowledge, in which people of any group within the population or level at which they are located can perceive the problems that affect individual and collective well-being, making clear the causes and determining the means to solve these problems. In order to move from information to action and to generate social transformation, it is necessary to promote a set of values in individuals and to make these values part of their actions; some of the values involved in education are austerity, respect, solidarity, responsibility, empathy, and coherence. To be able to incorporate these values into our daily lives, it is necessary to know them, understand them, and add them to education-related activities. It is not enough to make campaigns and projects to improve the environment if you do not set your own goals for those actions, as well as and understand the meaning they have in the community and the future of life on the planet.

It is necessary to emphasize the importance of educators as trainers of values since they are the ones who must transmit their principles to their students, thus contributing to the desired transformation of values in society. It is necessary to understand that teachers, at all levels and areas of education, transmit their own principles oriented to the educational model we want, which is why education is fundamental in this aspect. Showing an interest in research, from the conceptual point of view as well as in the change of attitudes and behaviors, to the development of methodologies and didactics of sustainable education (Figure 6.1). 
Figure 6.1 Example of the bad habits that society causes in the environment; generating pollution and secondary damages

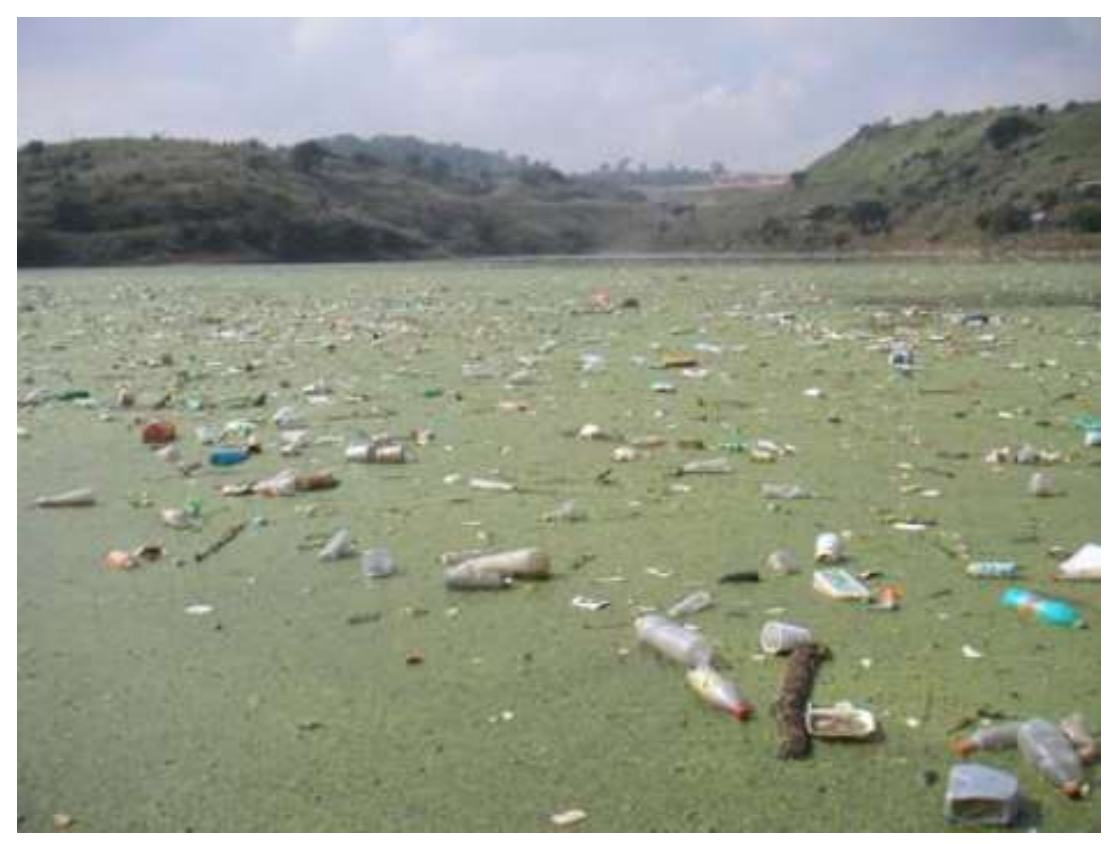

Source: Cantú, 2016

\section{Principles of sustainable development}

The historical process is marked by the expansion of the mode of production, by the technological patterns generated, by economic rationality guided by the purpose of maximizing profits and economic surpluses in the short term, by a division of labor and the unequal exchange of goods between nations. In order to understand environmental problems (Niño-Castillo, et al.; 2020), it is important to have a framework that accounts for their complexity, analyzing the physical characteristics of the environment connected to political, economic, and social conditions (Niño-Gutiérrez, 2008). We face a civilizational crisis; this crisis requires changing the development model and building another one that contributes to restoring the balance between the ecological, economic, and social aspects: sustainable development.

It is important to emphasize that the human species has interacted with the environment and has modified it (Niño-Gutiérrez, 2018). As a result, environmental problems are not simply new problems but have been present for a long time. However, the difference now is that we intend to solve them through education. In this context, education focusing on sustainability has an important role in facing this challenge as it promotes innovative learning. The values of contemporary society are challenged because these values lead to human decisions, thus leading to the root cause of the environmental crisis. The fundamental purpose of education is to ensure that both individuals and societies understand the complex nature of the environment, resulting from the interaction of its different physical, biological, social, cultural, and economic aspects. This will reorient the various disciplines and educational experiences through the acquisition of knowledge, values, skills, and practices that lead them to responsibly and effectively participate in the prevention and solution of environmental problems, but above all in environmental quality management.

Education is key to understanding the existing relationships between natural and social systems and should promote the consideration of values and behaviors that favor the effective participation of the population in the decision-making process (Niño-Gutiérrez, et al.; 2021). Although it is a lifelong process and not only limited to the educational sector, the pedagogical contribution to environmental activities is fundamental because it reforms the duties and rights of the human being. It becomes an element that respects all forms of life and questions the established economic-social model, which perpetuates unsustainability. Education can and should be a strategic factor that is not found in the established development model to reorient it towards sustainability and equity, which should be reflected by the behavior of man improving with respect to his environment and becoming a subject capable of changing the environment with a sustainable vision that lasts from generation to generation (Niño-Gutiérrez, 2017). In the 1960s, in the United Nations Organization (UNO), the governments of the world questioned the established growth model and the impact it had on the environment. Since then, several programs have been implemented to stop the environmental degradation of the planet. 
However, it was not until the 1980s that the World Commission on Environment and Development (WCED) first spoke of sustainable development as an integral process since it demands commitments and responsibilities from the different representatives of society in the application of the economic, political, environmental and social model, as well as the consumption patterns that determine the quality of life. The main objective of sustainable development is to meet present needs without compromising the ability of future generations to meet their own needs, i.e., the development of man and his environment can be sustained indefinitely over time without exhausting the material or energy resources required to function in a balanced way. A concept that assumes that the world is not as vast and limitless as previously thought, so sustainability requires holistic approaches to deal globally with the planetary emergency of pollution, ecosystem degradation, resource depletion, and uncontrolled growth of the world's population.

In 1972, at the conference on the human environment held in Stockholm, the urgency was expressed to adopt an international environmental education program with an interdisciplinary approach and an academic and extracurricular approach. However, it was not until 2002 at the World Summit on Sustainable Development that an international implementation plan was created to promote education for sustainable development, and this plan was launched in January 2005. Likewise, in the United Nations Decade of Education for Sustainable Development, the objective is to encourage governments to contribute to sustainable development by including measures in their educational plans with four fundamental pillars: learning to know, learning to live together, learning to do, and learning to be. In this manner, principles, values, and practices of sustainable development are integrated into all stages of education, encouraging behavioral changes that are necessary to preserve in the future the integrity of the environment and the viability of the economy for the coming years.

It is important to highlight the achievements of sustainable development, which implies the implementation of a continuous adaptation of systems of thought processes and actions that require creativity, flexibility, and critical reflection. This is in addition to changes in the three levels of government that include the fight against poverty, the rationality of production, and consumption patterns for the conservation of biodiversity since sustainability is not only related to ecological policy but also the fight against poverty and social equity.

Sustainability can be defined as a process of improving the living standards of the population of a locality that encompasses four areas: first is the political-administrative, which includes municipal initiatives to promote and coordinate different types of local development programs, this requires a democratic policy of financing and separation of public spending. The second area is the economy, which refers to local initiatives to generate greater productive capacity. The third area is sociocultural, which is the promotion of equal opportunities, and the establishment of links between civil society to enhance the capacity for action and participation in equitable and balanced local development. Lastly, the fourth area is called educational and is responsible for promoting lifelong learning opportunities for all people established in a specific region (Table 6.1)

Table 6.1 Attributes of sustainability for efficient development

\begin{tabular}{|l|l|}
\hline \multicolumn{1}{|c|}{ Category } & \multicolumn{1}{|c|}{ Attributes } \\
\hline Sustainability devil & $\begin{array}{l}\text { Accepts changes in current production processes to reduce environmental impact; } \\
\text { conservation is necessary for economic growth.Technical solutions to } \\
\text { environmental problems are emphasized. }\end{array}$ \\
\hline Strong sustainability & $\begin{array}{l}\text { Accepts the need for radical changes in the economic model and society to facilitate } \\
\text { an equitable sharing of environmental costs and benefits (intra- and inter- } \\
\text { generational equity). Stresses the need to ensure the survival of species and the } \\
\text { protection of critical environments beyond their possible economic use. }\end{array}$ \\
\hline Super-strong sustainability & $\begin{array}{l}\text { It accepts that the environment is valued in many different ways, in addition to the } \\
\text { economic one: there are also cultural, ecological, religious or aesthetic values, } \\
\text { which are equally or more important; the concept of "Natural Heritage" is } \\
\text { understood as a heritage that is inherited from our ancestors and that must be } \\
\text { maintained, bequeathed to future generations, and not necessarily sold or bought in } \\
\text { the market. }\end{array}$ \\
\hline
\end{tabular}




\section{Sustainable education in Mexico}

Mexico began to implement sustainable education later than other countries such as the United States, Europe, and Canada. The national development plan was presented, which at the moment called for changes to culture and prevention, sustainable use of resources, and improved quality of life. A pace of growth and inclusion was maintained in the different levels of formal education, in both formal and nonformal education programs; raised as one of the main tasks shared between the government and society, where education is a priority, training, and communication. In 1983, the first environmental education office was created as the Ministry of Urban Development and Ecology. The main objective was to analyze the environmental content of study programs and textbooks for preschool, primary, secondary and normal education. At the beginning of the 1990s, the World Wildlife Fund supported developing the first national strategy for sustainable education with its pedagogical proposals more aligned with national needs and characteristics.

It is worth mentioning that governmental efforts and the interest of academics have improved education in Mexico. It was considered that before creating environmental careers, first, it was necessary to complete several tasks. Those tasks included: modifying traditions, creating education centers at the regional and municipal levels, improving the ecological language to promote and create a new system of values, getting to know the environment, and promoting awareness and respect for interaction with the other elements of nature. Thus, primary school textbooks present a harmonious approach to sustainable education, and the development was started of support materials for teachers in different school environments. To establish better development of the plan, Mexico committed itself through the Ministry of Public Education and the Ministry of Environment and Natural Resources.

Using these resources, they made sustainable development a reality in the country through the school institutions of the different levels and modalities, to achieve the transition towards public and private life, to allow the citizens to participate in the decision-making process, to define the trajectories of national development to which it wants to reach, carrying out the principles of sustainability. Based on the commitment that Mexico managed to establish, the National Association of Universities and Institutions of Higher Education was formed. It sought to strengthen the contribution to sustainable development and to improve the quality of life in society, while creating the vision that the higher education system would contribute to sustainable education for the coming years. This was done along with the premise that none of the areas of knowledge be left out, which meant it was proposed that the creation, transmission, and dissemination of knowledge and its articulation with social and governmental organizations in a working mechanism that allows taking advantage of the strengths of sustainability in the country's development model.

A network of higher education institutions was founded, which promotes extracurricular environmental programs called the Mexican Consortium of Institutions of Higher Education for Sustainable Development. Its purpose is to promote the generation, discussion, and structuring of environmental and educational knowledge and skills that contribute to the development and strengthening of an environmental education that fosters individual and community human development committed to nature, society, and the individual. It is important to strengthen efforts to the maximum, such is the case of the definition of professional profiles, to think about differentiated profiles; to discuss the interdisciplinary approach of the field and its theoretical and methodological implications; to design curricular proposals oriented to the training of researchers and teachers in the field, at the same time that evaluation works are developed on the professionalization processes of sustainable education that allow progress and its redirection if necessary (Table 6.2). 
Table 6.2 Example of subjects corresponding to each state of Mexico about sustainable learning; established by the state education authorities of each state

\begin{tabular}{|l|l|}
\hline Estado & Programa \\
\hline Aguascalientes & Educación ambiental para la sustentabilidad en Aguascalientes \\
\hline Baja California Sur & Jóvenes sudcalifornianos por una cultura de la sustentabilidad ambiental \\
\hline Campeche & Educación ambiental en el estado de Campeche \\
\hline Chiapas & Educación ambiental para la sustentabilidad en Chiapas \\
\hline Distrito Federal & Educación ambiental para el desarrollo sustentable en el Distrito Federal \\
\hline Durango & Cultura del agua para la sustentabilidad en el estado de Durango \\
\hline Guerrero & Cultura ambiental: Reto de los Guerrerenses \\
\hline Hidalgo & Educación ambiental para la sustentabilidad en Hidalgo \\
\hline Jalisco & Educación ambiental, adolescentes y sustentabilidad en Jalisco \\
\hline Estado de México & Educación ambiental para la sustentabilidad del Estado de México \\
\hline Michoacán & Educación ambiental para la sustentabilidad en Michoacán \\
\hline Morelos & Hacia una cultura ambiental en Morelos \\
\hline Querétaro & Cultura ambiental en Querétaro \\
\hline Quintana Roo & Educación y cultura ambiental para la sustentabilidad en Quintana Roo \\
\hline Tabasco & Educación ambiental para la sustentabilidad en Tabasco \\
\hline Tamaulipas & Educación ambiental para la sustentabilidad en Tamaulipas \\
\hline Hlaxcala & Educación ambiental para el desarrollo sustentable en Tlaxcala \\
\hline Veracruz & Educación para la sustentabilidad en Veracruz \\
\hline Zacatecas & Educación ambiental para la sustentabilidad en Zacatecas \\
\hline
\end{tabular}

Source: Flores, 2015

\section{Sustainability in the teaching-learning process}

Globalization is known as a process of international growth of financial, industrial, and commercial capital, the use of natural, human, and political resources, and any interchangeable activity between countries. This intensifies and changes international economic life when a series of actions that the countries themselves have planned for the achievement of sustainable development are added. When focused on determining the links or relationships of sustainable development, the picture becomes complex. And if the focus is on higher education, establishing a preference for making changes that societies have achieved over time, such as how a country develops in a globalized world and how to achieve sustainability in its development. In this, not only a partial change is proposed, but fundamentally a new lifestyle is sought and a new and better understanding of relations between countries. Higher education institutions assume a social commitment, responsible for promoting the development of science, technology, and activities oriented to cover humanistic aspects that support the integral training of citizens.

The aim is to promote participation, the solution and prevention of environmental problems, and the construction of future scenarios through strategic actions in research, teaching, dissemination, and extension, as established in the action plan for sustainable development in higher education institutions. Buildings and the built environment have an important role, especially because of the impact they have on the natural environment and the quality of human life that is expected. For example, sustainable architecture and design should take into consideration the conservation of natural resources, energy efficiency, the use of non-polluting materials and construction processes, low land use, social and ecological principles; and above all an aesthetic sensibility that as sustainable design significantly reduces the adverse human-generated impacts on the natural environment while improving the quality of life, and social and economic well-being.

All countries in the world have set great challenges, and one of them is to preserve natural resources so that future generations can count on them. All have agreed that education is the fundamental pillar to transform our way of life, making great changes that can lead to a quality life, always maintaining balance. Accordingly, education for sustainable development has been a world priority since 1987 when the concept was defined in the Brundtland Report; by 1992, more than 180 countries committed themselves to sustainable development at the United Nations Conference on Environment and Development in Rio de Janeiro; it was determined that national education systems should be linked to the environment, society, and the economy. 
With the priority of establishing principles, values, and practices of sustainable development in all aspects of education and learning, to address social, economic, cultural, and environmental problems, there are four main foundations for effective development: better access to quality basic education, realigning educational programs from preschool to university; this to instill the principles, knowledge, skills and perspectives and values related to sustainable development, always hand in hand with the commitment to fulfill the plans in terms of their objectives.

Education for sustainable development should not only focus on students at the elementary and higher levels but should not have an age limit to obtain knowledge and skills, aimed at the population in general, a community education, where each person can learn from his or her partner and at the same time from the experiences that arise from practice. Since the emergence of implementing skills for sustainable development, there has been criticism from some sectors linked to the field of education in Latin America, who argue that there are no novel contributions of this approach through the exploration of the relationship between education, cultural change, and sustainability. It is discussed as a favorable response to obtain novel aspects that could have a positive impact on conceptual development and practice. Specifically, it is considered that it has addressed aspects of the sociocultural aspects ignored by education focused on sustainability in other regions, how it considers culture is novel and could generate new ways of providing solutions with different alternatives to achieve the objectives and balance between all sectors.

A proposal that aims to contribute to all processes of sociocultural change in order to build a sustainable future, this movement arises at the global level, which means that its conceptual development and its principles have been promoted at conferences and in international forums by multilateral agencies such as the United Nations Educational, Scientific, and Cultural Organization (UNESCO) and the International Union for Conservation of Nature (IUCN). In Mexico, since 2001, the 32 states have been promoting the creation of plans, programs, and strategies for environmental education, training, and communication, while simultaneously carrying out a series of inter-institutional actions on the education environment, with the participation of the National Association of Universities and Institutions of Higher Education (Asociación Nacional de Universidades e Instituciones de Educación Superior).

In the different global discourses that have been presented to make known important data on how to carry out sustainable development, the possibility of rethinking the relationship between the cultural dimension and the sustainability of societies is mentioned. Such a situation could generate new ways of interpreting the problems, of looking for solutions, and alternatives to improve the desired results.

Specifically, the approach of sustainable education in Latin America has tried to incorporate the sociocultural dimension in its work, but this does not mean that it diminishes all the contributions that have been generated, which is why it is important to reflect on its proposals and promote progress in different areas and on different topics, since it is a critical exercise for any discipline that intends to contribute to change towards a more sustainable future.

In education for sustainability, different areas must be considered to make it known that it is being carried out correctly and efficiently. It is characterized to describe seven areas which are the following ones:

Political dimension Its objective is to promote the development of qualifying subjects, expansion of social management spaces, dialogue, respect, and individual participation and citizen participation.

Ecological dimension Promotes the sustainable use of natural resources; establishes a social commitment to build appropriate controls of emissions and waste generation derived from production; and generates human resources capable of generating scientific and technical knowledge about ecosystems.

Epistemological and scientific dimension One of its goals is to reform the methods of knowledge production, interdisciplinarity, the internalization of the environmental dimension to the object of knowledge of each discipline, the transformation of educational profiles, programs, and the recognition of traditional knowledge. 
Pedagogical dimension This refers to innovative proposals that guarantee quality education for all, the planning of processes focused on learning, facilitating the understanding of reality and its transformation at the personal and community levels, creatively addressing learning needs, the development of workplace competencies and attitudes for life, work, organization, and the construction of learning communities.

Ethical dimension It reveals the rethinking of the role of human beings in the world, analyzing the value building that lies behind knowledge. It is the renewal of values, an ethics based on cooperation and respect for nature, dialogue, and democratic and equitable coexistence among the members of society.

Economic dimension Promote that individuals and social groups reflect on the ecological impact of the current economic model, generating awareness and engaging with social trends concerned with sustainable construction.

Cultural dimension Party to recognize the cultural set of traditions and community values of the different communities, recognition of plurality and respect for different worldviews, and the recovery of traditional systems of community organization for the use of natural resources.

It is intended to have an orientation towards the basic principles of education, achieving the formation of individuals aware of their environment and respectful of all living beings. For this, an educational process based on a broad and integral concept of education is required. That is to say that its purpose is to develop a person who can learn to know, to learn to live collaboratively, to learn to do, to learn to be.

The concept should be understood broadly, as it encompasses various issues that are of great relevance for the planet, such as climate change, biological diversity, disaster risk reduction, cultural diversity, poverty reduction, gender equality, health promotion, peace, and human security, among others.

\section{Education-based on sustainability}

Nowadays, with all the scientific and technological contributions that are available, better and efficient results have been achieved in the educational sector, as well as in different sectors for greater growth and development. However, sometimes there is a sensitization that has a certain influence on the production systems, to reach the new lifestyles that we want to implement, mainly in industrialized countries, which are the main ones that have introduced new unsustainable models. A clear example is the burden of consumption by increasing in an unattainable way. For this reason, some social, economic, and environmental problems, which in turn are related to each other, are commonly found and constitute development problems that could later generate different problems for the life of mankind.

Sustainable development is fundamentally about the relationships between people, the way of leading daily life, according to the environment where they live, and to be able to maintain a balance between both, as well as the social and economic development models are present. The main one is the human element, making it a priority to establish the relationships between the social and economic elements of the population in addition to the natural resources they have, in order to achieve positive results or in the worst case, the process is totally negative, and the objective of maintaining a balance between each of the elements is not achieved. It is very common that it proves difficult on most occasions to carry out the idea of sustainable development, for all the actions that must be considered to be able to execute it efficiently. However, there are feasible and simple options to start or emphasize, a way to achieve it, starting with the identification of the needs that justify a particular project, analyzing which would be the benefits or positive responses that would be had to achieve them. The needs are classified in the following way:

\section{Materials}

They are classified in everything related to the welfare of the person, such as food, physical security, housing, everything that ensures a quality life. 
Social and spiritual The individual aspirations that one has as a person; education, freedom, recognition. Environmental quality To be able to have access to a clean and healthy environment, a sustainable ecosystem. Equality To be able to enjoy the diversity that is presented, taking into account future generations, providing them an opportunity to share in the well-being of the environment and society (Figure 6.2).

\section{Figure 6.2 Quality of life parameters}

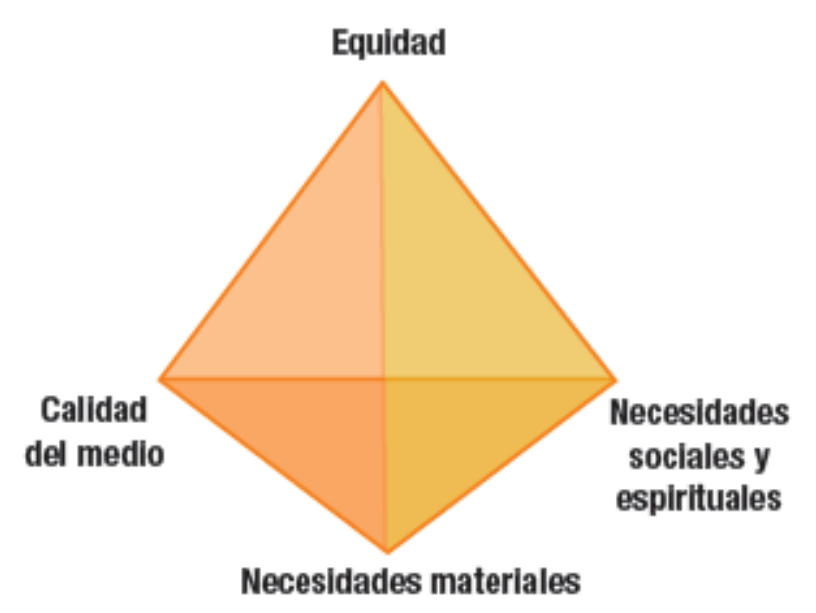

Source: Aznar, 2010

Sustainable development is intended to be a goal, but to reach it, it should start not only as a goal but also to establish a process to facilitate actions and not only through the application of techniques and programs as it is usually done for other methods. As any social process mainly involves values, beliefs, and behavior of the person or society, to be able to develop in an efficient and effective way, education, specifically sustainable education, should be more deeply involved in a strategic way, and this will allow establishing from the beginning a development model with a focus on sustainability and equality. Education facilitates the ability to understand how everything is related and to achieve a balance between natural and social environments without affecting any of them while obtaining great benefits such as achieving an international movement of thought and action promoting respect for the care of people as well as the environment and the planet's resources. This will provide an excellent basis to contribute to the values that support respect, care, and responsibility. Consistency within education for sustainability allows us to have better training to develop and acquire behaviors, practices, and/or skills that allow all human beings to meet the basic needs to live a full life.

The educational process promotes innovative learning and is characterized by anticipation and participation. This gives the capability to understand and get involved in everything one wants to do. A clear example that can be seen from the elementary school level, whose main objective is to provide students with the skills and abilities, as well as fundamental knowledge so that they can develop and implement innovative projects. In the future, that will allow them to have more opportunities to grow in everyday life; instilling leadership in their values to achieve great goals, establish their businesses if they wish, creating and promoting the creation of jobs in regions or sectors where it is necessary to have greater development, as well as growth in the economic sector, reflecting a balance to have more growth at a personal level and as a society.

However, the search for sustainability not only depends on education; there are a variety of factors that influence the development of processes and values that promote sustainability. Some of which are: economic organization, participation in decision making, social interrelationships, among others; it should be considered important that each one is needed to achieve sustainability because if any aspect fails, it would be difficult to develop it correctly. That is why it is necessary to inculcate the principles and foundations of sustainability, from the basic level of education, to achieve it correctly in the coming years. Education is a social instrument of transformation for society itself. If one of the other elements or most of them do not take into account the participation to make the necessary changes, it would be impossible for the education sector alone to achieve the desired transformation, production choices, consumption patterns, and the established development makes it improbable to promote sustainable development without establishing changes in these structures. 
Education with a focus on sustainability is aimed at all types of people, regardless of their age, and develops mainly from the perspective of lifelong learning, implements all types of learning modalities; non-formal and informal forms. It tries to reflect the concern for life and education of excellent quality, to provide people with the knowledge to be able to understand what is happening (knowing), to complement within society, to feel part of it (knowing how to be), in addition, to achieve participation in the processes of development, creating the ability to establish skills and develop new ones over time (knowing how to do Figure 6.3).

Figure 6.3 The relationship and execution on how to implement knowing, knowing how to do, and knowing how to be

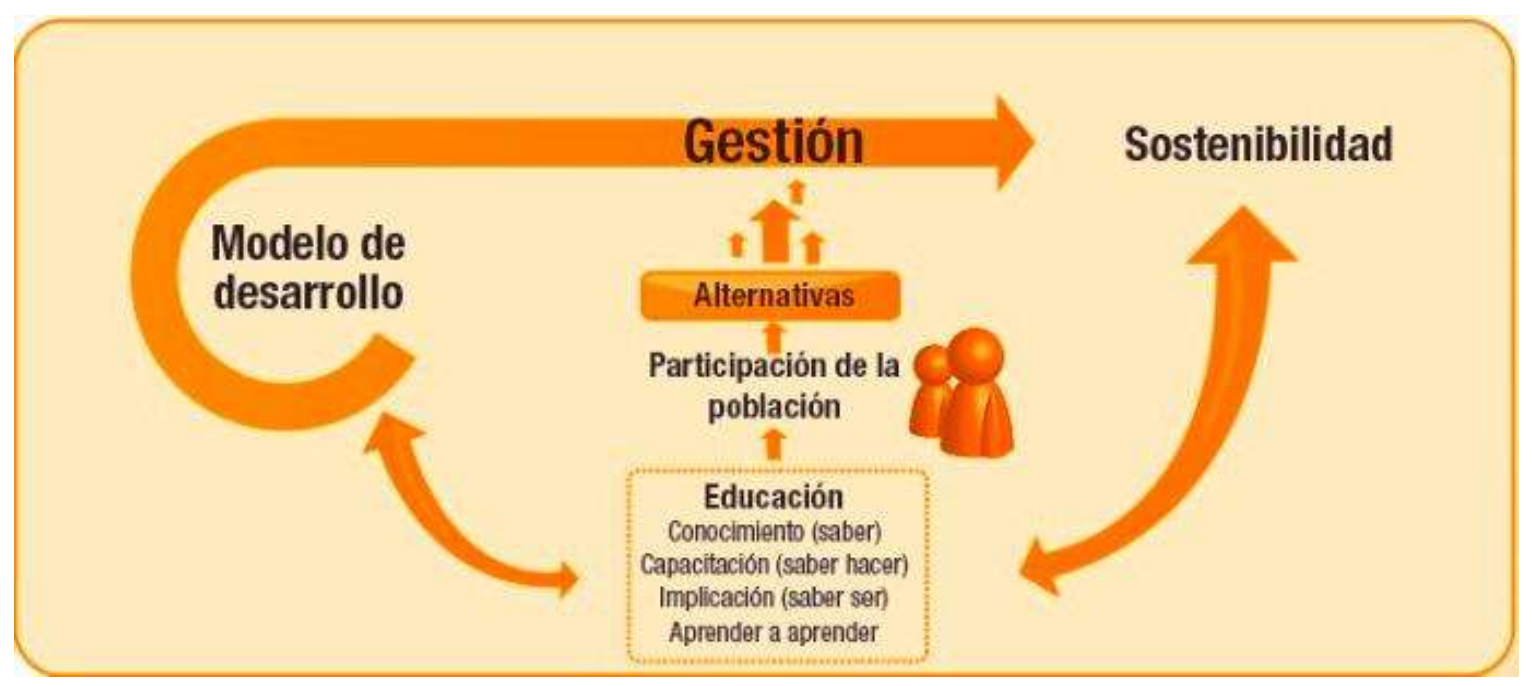

Source: Aznar, 2010

The practices and knowledge that are initially learned will be applied to individual and collective habits through small decisions or activities that are carried out in daily life. Therefore, when establishing plans or strategies mainly in education, it is important to emphasize that this allows learning for sustainability. But above all, it is obtained through practice and models to follow that are carried out in daily life.

It should not be limited to only exercise it individually, but to be able to develop the ability to collaborate with others through teamwork, thereby achieving a change in social structures, personal and group participation is achieved in the search for efforts to find better mechanisms and frameworks to move towards sustainability.

To provide knowledge about sustainable development through theories that facilitate obtaining skills and abilities, with the objective of implementing them in a correct manner. In the first place is theoretical rationality, which allows the application of scientific knowledge to improve educational practice. It is found in the rise of a renewed conceptual apparatus of science that transcends the fragmentary objectivity of the reductionist analyses of the analytical and mechanistic approach. It allows, through multidimensional and comprehensive explanations, to offer cognitive and methodological proposals more in line with the human-social sciences and with the need to connect the natural, socioeconomic and cultural phenomena of the environment and development in an interdisciplinary manner. Concerning this perspective, education could focus on reviewing and offering methodological proposals for the understanding of the socio-environmental problems of development, the understanding of the interaction between human beings and the natural and sociocultural environment, as well as the relationship between thought and action in the development of the competencies required for sustainable human development. As a second point, practical rationality is established, since it facilitates the recreation and new construction of knowledge from experience, provided by the application of scientific knowledge in the different fields of action; it implies a way of reintegrating educational theory and practice that requires the exercise of a reflexive knowledge to do, but also a reflexive doing to know. With regard to education, it is specified in reflecting critically on the aims and objectives of education for sustainable human development, specifying the concepts that relate to the environment, education, science, and sustainability, as well as being able to analyze and assess the world reports on development published annually by international organizations, such as human development. 
The reports represent important documents for the analysis and understanding of the reality of human development, to be able to establish response options and sustainable proposals, to build, contribute models and systems that allow to indicate and evaluate the process of education for sustainable development.

Finally, there is ethical rationality, which allows us to change our representations of reality from an ethical system, such as the reintegration of educational theory-practice. To the extent that we act guided by different motives, which have to do with collective value systems, it also calls for a type of information on values, of an ethical nature, to commitments that guide education.

This rationality involves in the very definition of sustainable development the moral conception and the ethical attitude from fostering the values of sustainability; the ethics of sustainability; it is also economic, social, and political ethics, which can encompass different areas of interaction, for example, the social, ecological, political, economic, between society and its institutions.

The set of these interactions makes up the triple dimension of ethics for sustainability, the first is defined by the values that define the individual rights that pertain to the relationships between human beings; these are the rights of the first generation, the second is defined by the values that define the social rights that correspond to the relationships between human beings and social organizations; and the third is defined by the values that specify the rights related to the environment, peace and the development of society.

These three types of rationality serve as a reference to specify in a coherent manner. The basic competencies for sustainability to be developed in the curricula and the different study paths, from theoretical rationality, the cognitive competencies can be specified (field of knowing), referred to the critical understanding of the problematic of global sustainability from the practical rationality, procedural competencies can be specified (field of expertise knowledge), referring to the acquisition of skills, strategies, and procedures for decision making and the implementation of sustainable actions; from the ethical rationality, attitudinal competencies can be specified (field of experiential knowledge), referring to the clarification and development of attitudes and values related to sustainability.

\section{Fundamentals of a sustainable education}

Education for sustainability must share all the features of a quality educational experience, incorporating the values of sustainable development in the teaching-learning process; highlighting mainly the values on which it is based, those that allow to carry out development in a more efficient way, to be able to make a selection in which the most convenient ones can be chosen to be able to exercise them during the process, similarly with critical thinking that allows facing the problems that may arise in different circumstances, giving a favorable response to correct the problems or seek ways of a solution with the interaction of different people applying teamwork, focusing on reaching the goal and showing the commitment to achieve sustainability.

In order to make decisions, it is necessary to integrate all the people who work together to reach the end results. This helps to have a greater contribution of ideas when a problem arises, as well as to establish some improvement in the development process, including those related to the environment and the way of learning. Different means can be used to achieve the necessary skills in the sustainability approach, such as didactic resources, the experiences of people who may have more time in practice, the realization of debates; this will allow building a joint form of knowledge either on a local or global scale with a focus on development problems.

It establishes the spirit that should preside over the design and implementation of education programs for sustainability, developing participation in planning and management for sustainable development, achieving in educational practice the knowledge of the reaction between the problems and uses of resources of each region is linked to local development.

The participation of the different social stakeholders in the decisions and actions to be taken is important since it affects the type of development to carry out an effective and sustainable model. 
The goal is to involve the population in the planning and management of development, to assume the role of social dynamization, seeking complicity in good practices.

The field of sustainable education is undergoing a continuous transformation, a permanent construction, and reconstruction where a wide range of theoretical and methodological approaches, postures, and languages converge, making it a complex field of knowledge and practices. The challenge of education in this globalized world is to contribute to reorient our patterns of action towards the new paradigm, to favor the progressive transformation of patterns of resource utilization and personal interrelationships based on criteria of ecological sustainability and social equity. The transformations required by educational systems are important not only to solve the problems of coverage and quality but also to incorporate this new ethic, without which it is very difficult to think that new paths to social development and sustainability can be opened (Table 6.3).

Table 6.3 Continuing education courses

\begin{tabular}{|c|c|c|}
\hline Curso & Institución responsable & $\begin{array}{c}\text { Dirigido a profesores de } \\
\text { niveles y modalidades }\end{array}$ \\
\hline $\begin{array}{l}\text { Cambio climático: ciencia, } \\
\text { evidencia y acción }\end{array}$ & $\begin{array}{l}\text { Centro de capacitación y } \\
\text { educación para el desarrollo } \\
\text { sustentable, SEMARNAT-SEP }\end{array}$ & $\begin{array}{l}\text { Inicial, preescolar, primaria } \\
\text { (regular e indígena), secundaria, } \\
\text { telesecundaria, educación física, } \\
\text { especial, extraescolar y artística } \\
\text { CAPEP }\end{array}$ \\
\hline $\begin{array}{l}\text { Prácticas educativas para el } \\
\text { desarrollo sustentable }\end{array}$ & $\begin{array}{l}\text { Universidad Tecnológica } \\
\text { Emiliano Zapata del Estado de } \\
\text { Morelos }\end{array}$ & $\begin{array}{l}\text { Inicial, preescolar, primaria } \\
\text { (regular e indígena), secundaria, } \\
\text { telesecundaria, educación física, } \\
\text { especial, extraescolar y artística }\end{array}$ \\
\hline $\begin{array}{l}\text { Que cambia con el cambio } \\
\text { climático }\end{array}$ & $\begin{array}{l}\text { Dirección General de Formación } \\
\text { Continua de Maestros en } \\
\text { Servicio }\end{array}$ & $\begin{array}{l}\text { Inicial, preescolar, primaria } \\
\text { (regular e indígena), secundaria, } \\
\text { telesecundaria, educación física, } \\
\text { especial, extraescolar y artística } \\
\text { CAPEP }\end{array}$ \\
\hline $\begin{array}{l}\text { Economía, Ambiente y Sociedad, } \\
\text { ejes de la Sustentabilidad: un } \\
\text { enfoque para la enseñanza } \\
\text { básica }\end{array}$ & $\begin{array}{l}\text { Universidad Tecnológica de Tula- } \\
\text { Tepeji }\end{array}$ & Secundaria \\
\hline
\end{tabular}

Source: Flores, 2015

The strategies are aimed at moving from quantitative growth to product development based on efficiency, innovation, clean production, and the practice of the 3Rs: recovery, recycling, reuse. It also implies making qualitative changes in the investment pattern, both public, private, and social, redirecting it towards sustainable projects with high social profitability; consumption must be coherent with the regenerative and assimilative capacities of the global systems that sustain life.

Environmental strategies focus on conserving genetic, species, and ecosystem biodiversity, halting the extinction and destruction of habitats, recovering degraded ecosystems, using farmland more efficiently, preventing global warming and the destruction of the ozone layer.

Implement strategies to reduce the use of fossil fuels and replace them with other sources and properly manage domestic and industrial waste; human strategies focus on reducing the population explosion and reducing migration to cities by promoting sustainable rural development, adopting measures to minimize the consequences of urbanization, generating policies for equal access to basic resources with health and education programs, protecting cultural diversity, stimulating citizen participation and combating absolute poverty. It is necessary to change the population's consumption patterns to avoid excesses that produce over-pollution, reduce the growing disparity in salaries, generate more sources of employment for consumption and local and regional markets.

In the case of technological strategies, the aim is to adopt more efficient and cleaner technologies, less intensive in the use of natural resources and energy consumption; to preserve traditional lowpollution technologies for support. 
The key point is to create a proposal of dematerialization that allows the dominant paradigm to defend the idea of a planet with inexhaustible resources, largely on technology. It is possible to achieve a significant dematerialization if the most efficient technologies that exist in the market are intensively applied, and in parallel, the most impacting consumption patterns are changed.

\section{Conclusions}

Sustainability has been present in human life for decades. However, in recent years it has had a greater impact due to the great demand that has been generated for the acquisition of products, services, technology, among other things; as well as the way of life that developed countries have been living, the excessive exploitation of natural resources, not taking into account the consequences that could be generated if they do not have the necessary considerations to establish sustainable development, trying to bring a balance in the social, economic, and environmental spheres.

However, it should be noted that the education sector has great importance regarding implementing sustainable development since education instills in students the basic principles, knowledge, skills, values, and above all, creates awareness about the importance of sustainability, in addition to the great advantages that can be obtained by carrying it out. In this way, we can enjoy a quality life hand in hand with sustainability; also, it is easier to acquire everything mentioned since it begins to provide such knowledge from an elementary level to the higher levels of study.

If sustainable development is established and carried out, great benefits could be obtained. In addition to promoting the culture that is part of life, this will allow more efficient implementation on a daily basis. A great advantage is that by introducing the principles of sustainability to the present and future generations, we have the teaching of how to implement it in society, with all the skills and abilities that they can acquire to achieve a change; creating and promoting employment, the creation of innovative projects that lead to greater development, either in the regions where they are presented with greater requirements as well as in large cities and countries. Remember that to function in an efficient manner, we must work individually, also work together as a team where all people can get involved for better results, fulfilling the principles and values that sustainability contains.

\section{References}

Aznar, P. (2010). Education for sustainable development: theoretical reflections and proposals for action. Valencia, Spain: University of Valencia (EDETANIA 37).

Batllori, A. (2008). Environmental education for sustainability: a challenge for universities. Morelos, Mexico: Universidad Nacional Autónoma de México, Centro Regional de Investigaciones Multidisciplinarias.

Bustamante, T.; Salgado., J., Iturio., J. \& Ferrer., G. (2017). Education for sustainability. Guerrero, Mexico: Autonomous University of Guerrero, EON Editions.

Cantú, P. (2016). Sustainability and Education. Nuevo León, Mexico: Universidad Autónoma de Nuevo León.

Colín, N., Llanes, L. \& Iglesias, D. (2019). The educational system in Mexico, sustainable vision?. Revista CoPaLa, 1(9) 155-170.

Environmental education. (2008). Principles of sustainable development. Distrito Federal, Mexico: Instituto Politécnico, Innovación Educativa, Vol.8 Núm. 43 77-84 pp.

Flores, R. (2015). Environmental education for sustainability in secondary education. Electronic Journal "Research Updates in Education. 15(3):1-21.

Gaona, T., Chan, D. \& Corona, E. (2010). Sustainability in the teaching-learning process of integrated design. A perspective of the case of the faculty of architecture and design of the Autonomous University of Baja California, Mexicali B.C. Baja California Norte, Mexico: Autonomous University of Baja California. 
Hernández, J. \& Rivera, T. (2019). Education and sustainable development.

Hernández, M., Tilbury, D. (2006). Education for sustainable development, nothing new under the sun: considerations on culture and sustainability. Journal Iberoamerican Journal of Education. 1(40): 99109.

Maldonado, T. (2009). Environmental education for sustainability. Horizonte Sanitario. 8(2): 4-7.

Martínez, J. (2009). Education for sustainability. Ingurugela, Spain: Centro de Educación e Investigación Didáctico Ambiental, United Nations Educational, Scientific and Cultural Organization. (UNESCO).

Martínez, D. \& Gálvez, M. (2018). Environmental education for sustainability: synthesis for the teacher. Santiago, Chile: Division of Environmental Education and Citizen Participation Ministry of Environment Government of Chile (División de educación ambiental y participación Ciudadana Ministerio del medio ambiente gobierno de Chile).

Niño-Gutiérrez, N. S.; Luna Nemecio, J.; Niño-Castillo, I. N. \& Niño-Castillo, J. E. (2021). Quality of higher education: case study Universidad Autónoma de Guerrero, Mexico. ECORFAN Journal-Mexico. 12(27): $30-40$. https://www.academia.edu/52054532/Quality_of_higher_education_case_study_Universidad_Aut\%C3 \%B3noma_de_Guerrero_Mexico_Calidad_de_la_educaci\%C3\%B3n_superior_estudio_de_caso_Unive rsidad_Aut\%C3\%B3noma_de_Guerrero_M\% $3 \%$ \%Axico

Niño-Castillo, I. N.; Niño-Gutiérrez, N. S.; Niño-Castillo, J. E. \& Rojas-Copa, A. E. (2020). Territory, vulnerability and sustainability in the coastal-tourist strip of Acapulco bay. Journal of Bussiness Development Strategies. 6(17): 7-19. https://www.ecorfan.org/spain/researchjournals/Estrategias_del_Desarrollo_Empresarial/vol6num17/Jo urnal_of_Business_Development_Strategies_V6_N17_2.pdf

Niño-Gutiérrez, N. S. (2018). Sustainable tourism at "El Hondo" Natural Park, Spain. Revista ESPACIOS. 39(18): 9-15. https://bit.ly/3i1Mg5q

Niño-Gutiérrez, N. S. (2017). Natural heritage and Tourism in a higher education institution in South $\begin{array}{lllll}\text { Mexico. } & \text { ECORFAN } & \text { 28-38. }\end{array}$ https://rua.ua.es/dspace/bitstream/10045/106847/1/Nino_2017_ECORFAN-J-Mexico.pdf

Niño-Gutiérrez, N. S. (2008). Ambiente de la isla Roqueta de Acapulco, Guerrero, México. El Periplo Sustentable. 1(14): 5-25. https://www.researchgate.net/publication/242589677_Ambiente_de_la_isla_Roqueta_de_Acapulco_Gu errero_Mexico

Ruiz, I., Barraza, L. \& Ceja, M. (2009). Education for sustainability: analysis and perspective from the experience of two high school systems in rural Mexican communities. State of Mexico, Mexico: Universidad Autónoma del Estado de México, The Sustentable Periplo Magazine (Revista el Periplo Sustentable). 